\title{
SUSTAINABLE SOCIAL-ECOLOGICAL SYSTEMS: AN IMPOSSIBILITY?
}

\author{
by \\ Elinor Ostrom \\ Center for the Study of Institutions, Population, and Environmental Change \\ and \\ Workshop in Political Theory and Policy Analysis \\ at Indiana University \\ Center for the Study of Institutional Diversity, Arizona State University
}

\begin{abstract}
Given rapid changes in large-scale human and biophysical processes-carbon emissions, population increase and migrations, overharvesting and pollution leading to loss of species-scientists are worried that many of the social-ecological systems existing today may collapse by the end of the 21 st century. Is this an exaggerated worry? The thesis I will present is that the negative prognosis will indeed occur in many parts of the world if we do not worry a great deal about these processes and their consequences. More important than simply worrying, however, is the development of a strong diagnostic method for analyzing the diversity of processes and the multiplicity of potential social and biophysical solutions that are needed to cope effectively with these varied processes. Past efforts to impose simple solutions to these complex problems have frequently led to worse outcomes than the problems addressed. Our need today is building a strong interdisciplinary science of complex, multilevel systems that will enable over time a matching of potential solutions to a careful diagnosis of specific problems embedded in a social-ecological context. I will take some small steps toward this goal in my presentation.
\end{abstract}

Presented at the 2007 Annual Meetings of the American Association for the Advancement of Science, "Science and Technology for Sustainable Well-Being," 15-19 February in San Francisco. A revised and shortened version of this paper will be the perspectives paper of a special feature of the Proceeding of the National Academy of Sciences (USA) to be published in the fall of 2007. Support from the National Science Foundation (grant SES0083511), the Ford Foundation, and the MacArthur Foundation is greatly appreciated. 


\section{Sustainable Social-Ecological Systems: An Impossibility?}

Given rapid changes in large-scale human and biophysical processes-carbon emissions, population increase and migrations, overharvesting and pollution leading to loss of speciesscientists are worried that many of the social-ecological systems (SESs) existing today may collapse by the end of the 21st century. Chapin and colleagues (2006) warn us about the grave extent of worsening ecological conditions due to increased human activities. They urge us to consider a range of policy strategies that include diverse ways of improving the possibilities of sustainable social-ecological systems by creating diverse institutions that enhance learning and innovation at multiple scales. Unfortunately, much of the literature that focuses on remedies for the ecological threats we face predict disaster unless some preferred cure-all is adopted (Doyle 2006; Montero 2000; Rees 1992; Terborgh and Schaik 1997; Tipton 1995; Williams 2003).

Many have followed in Garrett Hardin's (1968) footsteps and predict dire consequences unless his first solution - government ownership - is imposed. The Task Force on Global Biodiversity of the National Science Board (NSB 1989) predicted that without solutions imposed by international bodies, most tropical forests will be diminished to fragments or lost entirely by the 21 st century. Even though there are over 100,000 protected areas around the world, including about $10 \%$ of the forested areas of the world (UNEP-WCMC 2004), many call for still further efforts to create and maintain protected areas as the only way to protect biodiversity (Lovejoy 2006; Terborgh 1999). Others argue that "the only way to avoid the tragedy of the commons in natural resources and wildlife is . . by creating a system of private property rights" (Smith 1981: 467; see also Wagner 1989). According to many analysts, sustainable SESs are impossible unless some particular panacea is adopted.

The central task of this paper will be to outline a method for diagnostic assessments of complex SESs. I hope to counteract the sense that it is impossible to achieve sustainability as well as the presumption that scholars have the tools to make simple, predictive models of linked social-ecological systems and deduce the universal solution - a panacea - to problems of overuse or destruction of resources. Pearce et al. (1989) wrote a popular textbook on environmental economics with the title of Blueprint for a Green Economy in which marketable permits were presented as the method for achieving optimal prices and sustainable development (see also Pearce 1988). Others have agreed that marketable permits are the optimal method for solving free-rider problems and coping effectively with common-pool resources (CPRs) (Armstrong and Sumaila 2001; Groves and Ledyard 1977; Yaron and Dinar 1982). ${ }^{1}$

\footnotetext{
${ }^{1}$ In recent times, economists have begun to call into question the presumption that privatization is a panacea and the only way to protect the commons (Kikeri and Nellis 2004; Rees 1992; Tietenberg 2002). Mulherin (2005)

challenges the presumption that there is one best structure for corporate governance. In contrast to panacea thinking,
} 
Sustainable Social-Ecological Systems: An Impossibility?

Elinor Ostrom

From a different policy perspective, privatization is not even considered a viable option by some environmentalists. When asked to reflect on ways to protect the environment, for example, John (2006) wrote that there were three ways to achieve sustained environmental protection: topdown government regulation, bottom-up grassroots governance, and middle-out civic environmentalism. Creating private property is not even among the options mentioned.

Serious proponents of broad collaborative approaches to solving resource governance problems are frequently "unnerved by the way in which these processes have been portrayed as a cure-all" (Conley and Moote 2003: 382). They are also upset, on the other hand, by "knee-jerk criticisms of collaborative processes that are based on an opposition to collaboration in principle rather than evaluation of specific processes and outcomes" (Ibid.). Conley and Moote call instead for serious research designs that clearly measure resource system structures and how diverse governance arrangements operate in the field (see also, Marshall 2005, in which the author stresses the need for adaptive management of complex resource systems).

Those researchers and practitioners who propose panaceas for solving complex environmental problems make two false assumptions. First they assume that all problems of a general type, such as air pollution or maintaining species diversity, are similar; and second, all of the people involved have the same preferences, information, and authority to act. Neither is true. For air pollution, the problem of controlling $\mathrm{CO}_{2}$, which spreads evenly in the atmosphere, is entirely different from the control of mercury, which falls near the source. The consequence of eliminating a species that is the only species at a trophic level in an ecosystem is catastrophic to ecosystem functionality as contrasted to the elimination of a species in an ecosystem characterized by many species at that trophic level. Experimental and field research has consistently found that individuals overtly facing the same situation vary substantially in their behavior (Atran et al. 2002; Camerer 2003). ${ }^{2}$ Large studies of land-use and land-cover change (Lambin et al. 2001) and of deforestation in particular (Kaimowitz and Angelsen 1998; Geist and Lambin 2001) have not found strong evidence for any single, ever present drivers of change.

Pritchett and Woolcock (2003) have strongly criticized the effort to find optimal solutions when "the" problem is actually the effect of imposed blueprint solutions recommended by scholars, donors, and governments for solving a problem (see, for example, Higgs 1996). Regrettably, proponents have not recognized that an effort to impose a standard "optimal" solution is "the" problem rather than "the" solution. Adams and Hulme (2001) raise the important question, "If community control is the answer, what is the question?" All too often, specific institutions are still prescribed as a cure-all or cursed as being evil. As Ackoff (2001: 8)

solid empirical studies of diverse property-rights systems have been undertaken by Eggertsson (2005), Libecap (1989, 2006), Libecap and Wiggins (1985), Blomquist et al. (2004), and Acheson (2003). See NRC (2002) for a synthesis of recent research related to diverse types of commons.

${ }^{2}$ I thank Scott Page for pointing out these two basic errors of panacea thinking (personal communication, October 2, 2006). 
has reflected, "panacea proneness is a diluted form of fundamentalism" rather than a method of serious diagnosis.

Scholars interested in improving the health of the planet need to adopt an important lesson from medicine. Before the turn of the 19th century, many treatments offered by professional doctors for ailments involved bleeding, purging, or blistering the patient. In his analysis of when medicine began to do more good than harm, Silverman (1993: 6) described earlier medical traditions: "When confronted by a sick patient, providers gather their purges and emetic, bare their lancets, and charge the enemy, prepared to bleed, purge and induce vomiting until the disease is conquered." In the collected papers of distinguished physician and writer Oliver Wendell Holmes, one finds that he espoused "doing nothing because doctors did more harm than good" (1988: 6). ${ }^{3}$

Sustaining natural resource systems is far too important a problem for scholars to espouse "doing nothing." We must make every effort to cope with these really wicked problems involved in avoiding ecological disasters. But, we also need to recommend caution about overusing simple blueprints and to develop diagnostic theories drawing on the lessons that can be learned from theoretical and empirical research on why some governance systems lead to improved performance of social-ecological systems and others lead to failures (Ostrom 1990). Brock and Carpenter (2007) illustrate how models of adaptive control processes in the Northern Highlands Lake District of Wisconsin are prone to panacea traps and recommend policy diversification as a means to escape from them. We will continue doing more harm than good if panaceas are recommended to solve resource problems rather than learning how to match potential solutions to a serious diagnosis of specific problems in the ecological and social context in which they are nested. Similarly, assuming that effective property-rights systems will simply evolve as resource units become more valuable (e.g., Demsetz 1967) is not an adequate understanding of the challenge of matching property rights and governance systems to particular ecological systems (Fitzpatrick 2006).

\section{Panaceas Frequently Fail}

We can learn from the history of past reforms that epitomized frequently proposed panaceas and failed (Scott 1998; Wilson 2002). Higgs (1996: 247) outlines how the efforts to turn the regulation of the Washington salmon fishery entirely over to the state government-a frequently recommended cure-all—generated "a legal and economic horror story," reducing the productivity of the fishery to a "small fraction" of what it was at the turn of the 20th century.

\footnotetext{
${ }^{3}$ While medical science has advanced substantially in the last century to find well-tailored responses to many specific medical problems, health professionals now face a substantial challenge of interpreting the volume of medical evidence to arrive at better diagnostic theories (Mulrow and Lohr 2001; Porter and Tiesberg 2006). Recent medical research has also stressed that individuals respond differently to the same medicine and urged more attention to personalized medicine. The search for cure-alls continues, however, in recent medical science (Kaiser 2006).
} 
Hansen and Libecap (2004) document how the government policy of allocating private-property landholdings in the U.S. Great Plains through the Homestead Act chose an inappropriately small farm size for this drought-prone region, leading to "waves of homestead busts" as hundreds of thousands of private farms failed when the periodic droughts returned between 1917 and 1921. Bacho (2004) documents how the presumed panacea of decentralization, as it was implemented in a multiethnic district of Ghana, has generated extensive ethnic conflict due to the lack of sensitivity to the history of multiethnic relationships in the way the decentralization framework was crafted. Gelcich et al. (2006) report how imposing a blueprint co-management system on a traditional lottery system for managing a marine ecosystem weakened the level of trust in a community and intensified conflict.

Clark (2006a,b) illustrates how applying bioeconomic models as panaceas has led to an excess of fishing vessel capacity, conflict among fishers and with fishing communities, and the enrichment of a select few. Von Weizsaecker et al. (2005) challenge the view that privatization is always the best option for delivering public services and present 50 case studies on best-case vs. worst-case experiences of efforts to privatize water, transport, and energy as they potentially impact climate change (see also van Berkel and van der Aa 2005). After providing an excellent overview of lessons to be learned from the experience of working with tradable permits in the field, Tietenberg (2002: 224) concludes that the "evidence seems to suggest that tradable permits are no panacea, but they do have their niche."

\section{The Challenge}

Thus, the challenge we face, as well articulated in the reports of the Millennium Ecosystem Assessment (http://www.millenniumassessment.org/en/index.aspx), is to avoid adopting standardized blueprint solutions but to search to find the appropriate types of solutions for specific niches and help to adapt these to particular situations. There are situations where some form of government ownership, privatization, decentralization, land reform, or community control of resources is an appropriate solution to a particular social-ecological problem. As Meinzen-Dick (2007) documents, however, the belief that these "solutions" always work needs modification if serious ecological problems are to be solved.

In order to use mathematical techniques to study various solutions for preventing inefficient resource use, scholars employ models that involve drastic simplifications of the structure and process of ecological systems as well as of the relevant social system related to these systems (Brock and Carpenter 2007). Investing in solutions posited as optimal based on such models is costly in time and resources. Further, when the "optimal" solution fails - and many have failed as discussed above - skepticism increases as to whether "any" solution is possible given that efforts to impose an optimal solution have not generated expected results. Further, some individuals and groups are frequently advantaged by so-called reforms even when net benefits are negative to the overall group. The advantaged then vigorously organize to resist efforts to 
Sustainable Social-Ecological Systems: An Impossibility?

Elinor Ostrom

learn from past mistakes and to adapt new rules better matched to an ecological system (Agrawal and Ribot 1999).

\section{What can be done?}

It is not enough just to call attention to the inadequacy of the panaceas that are prescribed as simple solutions to complex social-ecological systems. Korten (1980) long ago identified the danger of blueprint approaches to solving tough social-ecological problems and urged that policy makers adopt a learning process rather than imposing final solutions. Korten's advice is similar to that of Walters $(1986,1997)$ and the emphasis on adaptive management in contemporary analyses of complex adaptive systems (Gunderson and Holling 2002; Holling 1978; Janssen 2002). Unfortunately, the preference for simple solutions to complex problems continues to be strong even after years of challenge (Epstein 1997).

To build a strong field of sustainable science (Clark and Dickson 2003; Clark et al. 2005) and move beyond panaceas, one needs to build on the work of scholars who have undertaken careful, well-documented, and theoretically sound studies of ecological systems, socioeconomic systems, and linked social-ecological systems (Berkes and Folke 1998; Berkes et al. 2003; Carpenter and Brock 2003; Dasgupta and Mäler 1995; Lee 1993; Levin 1995, 1999; NRC 2002). We should stop striving for simple answers to solve all complex problems (Axelrod and Cohen 2001). Social-ecological systems are complex, and the problems of overharvesting and misuse of ecological systems are rarely due to a single cause. Holling et al. (1998: 352) identified the structure of the problems involved:

The answers are not simple because we have just begun to develop the concepts, technology and methods that can address the generic nature of the problems. Characteristically, these problems tend to be systems problems, where aspects of behaviour are complex and unpredictable and where causes, while at times simple (when finally understood), are always multiple. They are non-linear in nature, cross-scale in time and in space, and have an evolutionary character. This is true for both natural and social systems. In fact, they are one system, with critical feedbacks across temporal and spatial scales. Therefore interdisciplinary and integrated modes of inquiry are needed for understanding. Furthermore, understanding (but not necessarily complete explanation) of the combined system of humans and nature is needed to formulate policies.

The conceptual structure of these problems needs to be characterized as a rugged landscape with many peaks and valleys. Reducing the number of possible solutions for finding higher peaks to one or a few optimal strategies is grossly inadequate for reaching creative solutions to challenging problems (Page 2007). One can become fixated on a low conceptual hill related to particular variables that do not help in finding better solutions for many of the other SESs. Rather, we need to recognize the complexity and begin to identify the relevant ecological 
variables, such as spatial and temporal variability, that affect the incentives and actions of actors under diverse governance systems. We need a strong diagnostic approach that identifies the nested attributes of a resource system and the resource units produced by that system that jointly affect the incentives of users (given their own complex set of attributes) within a set of rules crafted by a local, distal, or nested governance system to affect interactions and outcomes over time (Young 2006). Further, we need to enable resource users and their officials to experiment with adaptive policies so as to gain feedback from a changing SES before a severe transformation adversely overcomes them (Carpenter and Brock 2004; Carpenter and Gunderson 2001).

\section{A Nested Framework for Analyzing Interactions and Outcomes of Linked Social-Ecological Systems}

Moving beyond panaceas to develop a cumulative capacity to diagnose the problems and potentialities of linked social-ecological systems requires serious study of the complex, multivariable, non-linear, cross-scale, and changing SESs described by Holling et al. (1998). We need to clarify the nature of each SES so we understand the niche involved and how a particular "solution" may help to improve outcomes or make them worse. And we should not assume that a solution will work the same over time. As structural variables change, participants need to have ways of learning and adapting to these changes.

A large number of variables have been identified by researchers as affecting the patterns of interactions and outcomes observed in empirical studies. After undertaking a careful analysis of the extensive research examining the factors likely to affect self-organization and robustness of common-property regimes, Agrawal (2002) identified more than 30 variables that had been posited in major theoretical work as affecting incentives, actions, and outcomes related to averting destruction of commons. Agrawal then raised challenging questions about how research could be conducted in a cumulative and rigorous fashion if this many complex and potentially important variables needed to be identified in every study.

\section{Decomposable Systems}

Scientific progress has been achieved in the past when scholars have recognized that complex systems are partially decomposable in their structure (Allen and Hoekstra 1992; Koestler 1973; Wilson 2002). Simon (2000: 753) describes nearly decomposable systems in the following manner:

They are arranged in levels, the elements at each lower level being subdivisions of the elements at the level above. Molecules are composed of atoms, atoms of electrons and nuclei, electrons and nuclei of elementary particles. Multicelled organisms are composed of organs, organs of tissues, tissues of cells. 
Three aspects of decomposability of complex subsystems are important for achieving a better understanding of complex SESs and approaching ways to improve their performance. The first aspect is the conceptual partitioning of variables into classes and subclasses. The second aspect is the existence of relatively separable subsystems in the world that are independent of each other in the accomplishment of many functions but can affect each other's performance. Third, whole complex systems are greater than the sum of their parts. The first aspect is essential for building coherent and cumulative scientific understanding and will be illustrated in Figure 1 and Table 1. The second aspect is essential for building solutions to complex SESs that are generating perverse outcomes. The third aspect makes it essential for scholars to recognize that combining variables $\mathrm{A}, \mathrm{B}$, and $\mathrm{C}$ can lead to a system with emergent properties that differ substantially from combining variables $\mathrm{A}, \mathrm{B}$, and $\mathrm{D}$.

\section{Developing the Conceptual Maps}

Let us now address the importance of identifying the conceptual tiers and linkages among variables that constitute an SES as it affects and is affected by larger and smaller SESs. At the broadest conceptual level, one can posit a general framework - a conceptual map - that can be used as the starting point for conducting the study of linked SESs. Figure 1 presents a simple, very general framework for what I hope captures the highest tier variables that scholars must analyze when examining linked SESs. ${ }^{4}$ At this broad level, one can begin to organize an analysis of how attributes of

- a resource system (e.g., fishery, lake, grazing area),

- the resource units produced by that system (e.g., fish, water, fodder),

- the users of that system, and

- the governance system

jointly affect (and are indirectly affected through feedback from) the patterns of interactions and resulting outcomes achieved at a particular time and place and how these may affect and be affected by larger or smaller socioeconomic and political settings in which they are embedded as well as by a larger or smaller SES.

Each of the eight broad variables shown in Figure 1 can be unpacked and then further unpacked into multiple conceptual tiers. ${ }^{5}$ How far down or up a conceptual hierarchy a researcher needs to proceed depends on the specific empirical or policy question under investigation. Further, many interactions and outcomes depend on the specific combination of

\footnotetext{
${ }^{4}$ This framework further elaborates the Institutional Analysis and Development (IAD) framework developed by scholars associated with the Workshop in Political Theory and Policy Analysis at Indiana University (Ostrom 2005) and to the framework developed by Anderies et al. (2004) for examining the robustness of SESs.

${ }^{5}$ The task of identifying which variations are subcategories of a more general variable is not to identify the relative importance of a variable. As discussed below, some crucial variables used in the design of successful governance systems are third- and fourth-tier ecological variables that are important in only some SESs.
} 
several variables at one or multiple tiers (Low et al. 2003; Netting 1976, 1981; Schlager et al. 1994). The direction and strength of impact of one variable frequently depend on the combination of other variables present (Poteete and Ostrom 2004a,b) as well as the past history of processes in the SES. Further use and development of this framework will hopefully enable researchers to develop cumulative, coherent, and empirically supported answers to three broad questions:

1. What patterns of interactions and outcomes-such as overuse, conflict, collapse, stability, increasing returns - are likely to result from using a particular set of rules for the governance, ownership, and use of a resource system and specific resource units in a specific technological, socioeconomic, and political environment?

2. What is the likely endogenous development of different governance arrangements, use patterns, and outcomes with or without external financial inducements or imposed rules?

3. How robust and sustainable is a particular configuration of users, resource system, resource units, and governance system to external and internal disturbances?

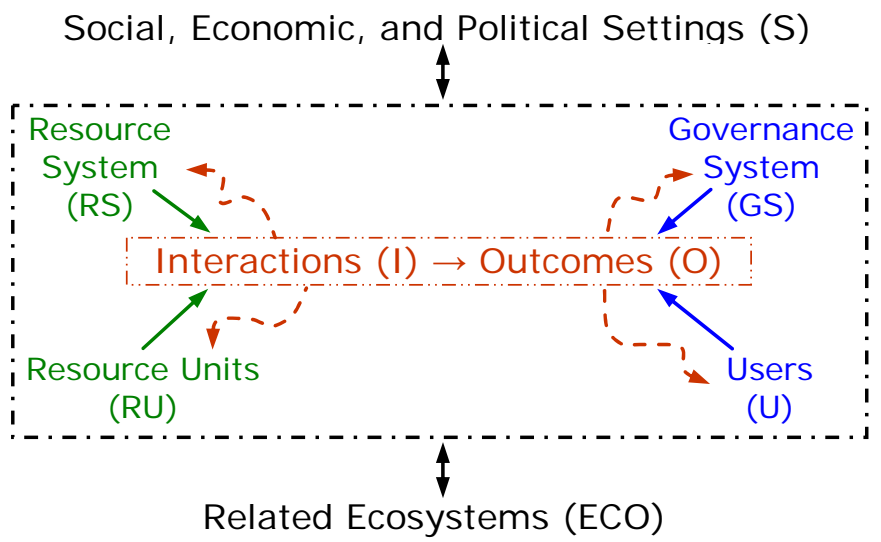

Figure 1. A Multitier Framework for Analyzing a Social-Ecological System (Straight arrows represent direct causal links; red, curved arrows represent feedbacks)

Since this is a decomposable system, each of the highest-tier conceptual variables in Figure 1 can be unpacked and related to other unpacked variables in testable theories relating the outcomes of human use to the structures of the relevant, linked SESs. Table 1 lists major secondtier variables that have been identified in multiple studies as impacting on diverse interactions and outcomes (Mitchell, et al., 2006; Moran 1995, 2006; NRC 2002, 2005; Ostrom 1999). There are now well over the 30 variables identified by Agrawal (2002) that enable an analyst to begin to unpack the framework and dig into an analysis. 
Sustainable Social-Ecological Systems: An Impossibility?

Elinor Ostrom

Table 1. Second-Tier Variables in Framework for Analyzing an SES

Social, Economic, and Political Settings (S)

S1- Economic development. S2- Demographic trends. S3- Political stability. S4- Government settlement policies. S5- Market availability.

Resource System (RS)

RS1- Sector (e.g., water, forests, pasture, fish)

RS2- Clarity of system boundaries

RS3- Size of resource system

RS4- Human-constructed facilities

RS5- Productivity of system

RS6- Equilibrium properties

RS7- Predictability of system dynamics

RS8- Storage characteristics

RS9- Location

Resource Units (RU)

RU1- Resource unit mobility

RU2- Growth or replacement rate

RU3- Interaction among resource units

RU4- Economic value

RU5- Size

RU6- Distinctive markings

RU7- Spatial \& temporal distribution
Governance System (GS)

GS1- Government organizations

GS2- Non-government organizations

GS3- Network structure

GS4- Property-rights systems

GS5- Operational rules

GS6- Collective-choice rules

GS7- Constitutional rules

GS8- Monitoring \& sanctioning processes
Users (U)

U1- Number of users

U2- Socioeconomic attributes of users

U3- History of use

U4- Location

U5- Leadership/entrepreneurship

U6- Norms/social capital

U7- Knowledge of SES/mental models

U8- Dependence on resource

U9- Technology used

\section{Interactions (I) $\rightarrow$ Outcomes (O)}

I1- Harvesting levels of diverse users

12- Information sharing among users

13- Deliberation processes

14- Conflicts among users

15- Investment activities

16- Lobbying activities
O1- Social performance measures

(e.g., efficiency, equity, accountability)

O2- Ecological performance measures

(e.g., overharvested, resilience, diversity)

O3- Externalities to other SESs

Related Ecosystems (ECO)

ECO1- Climate patterns. ECO2- Pollution patterns. ECO3- Flows into and out of focal SES. 
Sustainable Social-Ecological Systems: An Impossibility?

Elinor Ostrom

\section{Table 2. Examples of Third- and Fourth-Tier Variables for Resource Units}

Resource Units (RU)

RU1- Resource unit mobility

RU1-a Mobile resource units (e.g., fish, cattle, water)

RU1-a1- Spatial extent of movements

RU1-a2- Temporal aspects of movement

RU1-b Stationary resource units (e.g., plants, trees)

RU1-b1- Length of time to maturity

RU1-b2- Mechanisms for reproduction

RU2- Growth or replacement rate

RU2-a Length of time to maturity

RU2-b Migration patterns

RU3- Interaction among resource units

RU3-a Symbiotic interaction

RU3-b Competitive interaction

RU4- Economic value

RU4-a Subsistence value only

RU4-b Market value

RU4-b1- Highly volatile prices

RU4-b2- Stable market prices

RU5- Size

RU6- Distinctive markings

RU6-a Natural markings

RU6-b Artificial markings feasible

RU7- Spatial and temporal distribution

RU7-a Variable depending on nutrient availability

RU7- $b$ Stable and predictable niche locations 
In addition to the broad variables identified in Table 1, many more specific variables are identifiable at the third, fourth, and fifth tiers, and some will be used in the analysis below of failed versus successful SESs. Extensive research is currently underway to develop this diagnostic framework further and link it to rigorous empirical research findings. A major challenge is defining all variables so the conceptual logic of linking more specific concepts to more general concepts is clear and open to further discourse and development. Based on the foundational work of Allen and colleagues (Allen and Hoestra 1992; Ahl and Allen 1996), ecologists have developed and iterated nested frameworks for identifying types of ecological systems (see, for example, Josse et al. 2003, who identify nearly 700 types of ecological systems present in Latin America and the Caribbean). As a complement to this work, I have developed an extensive conceptual taxonomy related to governance systems (Ostrom 2005).

In the complex and changing world to be studied and in theoretical models of that world, interaction effects often occur among variables at one or more tiers. The storage available in a system (e.g., the amount of water that can be stored in a dam or carbon that can be stored in a forest) may differ by resource unit, so one would need to dig into third- or fourth-tier variables and the horizontal linkages among them for a meaningful understanding of storage. Thus, one needs to examine both vertical and horizontal relationships of a partially decomposable conceptual map. Further, both the temporal and spatial dimensions of systems are essential to include in analyses (Cash et al. 2006). Identifying which variables change rapidly or slowly is essential for the development of dynamic theories of system performance.

Listing a variable in this nested taxonomy does not mean that all identified variables are relevant for analyzing any particular research question. Rather, the long-term goal for scholars of sustainable science is to recognize which combination of variables tends to lead to relatively sustainable and productive use of particular resource systems operating at specific spatial and temporal scales and which combination tends to lead to resource collapses and high costs for humanity. Instead of a simple system to analyze, scholars and policy analysts face compound puzzles nested in compound puzzles (McGinnis and Williams 2001).

A recent paper by Tucker et al. (2007) illustrates the need to combine variables across the biophysical and social domains to address sustainability questions. Tucker and colleagues examine underlying biophysical factors (soil conditions, elevation, and slope) and strengths of local institutions as these affect forest conditions in hilly areas of Honduras and Guatemala, as well as how the institutions are themselves affected by the conditions of a forested resource. The specific variables that strongly account for outcomes in this study would not necessarily be as powerful in explaining outcomes in a flat plain with little variation in soil, elevation, and slope. The key is assessing which variables at multiple tiers across the biophysical and social domains affect human behavior and social-ecological outcomes over time. 
Sustainable Social-Ecological Systems: An Impossibility?

Elinor Ostrom

\section{Conditions Leading to the "Tragedy of the Commons"}

With this framework, we can now reconstruct Hardin's argument (1968) as including only a particular set of second-tier variables. He envisioned "a pasture open to all" in which each herder received a direct benefit from adding animals to graze and suffered only delayed costs from his own and potentially others' overgrazing. Translating his metaphor into a theory requires five assumptions: (1) no governance system is present (no GS) related to the resource system; (2) no human investments are made to improve the productivity of the resource system (the pasture) (no RS4); (3) the mobile individual resource units (RU1; the animals grazing on the pasture) are the private property of each pastoralist (given their distinctive markings that enable owners to claim them as their own (RU6-a)); (4) a sufficient number of users (large U1), given the size of the pasture, are using the pasture to adversely affect its long-term productivity; and (5) the resource users make decisions totally independently, without any local leadership or shared norms (no U5 or U6). Hardin then posits that individuals will pursue short-term, material benefits for themselves and ignore immediate consequences for others and long-term results for all. These assumptions about second-tier variables lead to a prediction of severe overharvesting.

While not a determinate theory, situations consistent with these assumptions, where relatively anonymous individuals independently make decisions and take their individual and immediate payoffs primarily into account, do tend to yield overharvested forests. Researchers have repeatedly generated a "tragedy of the commons" in experimental laboratories when subjects make independent and anonymous decisions in a CPR setting (Cardenas and Ostrom 2004; Cardenas et al. 2000; Casari and Plott 2003; Janssen et al. 2006; Ostrom et al. 1994). Making one small change, however, in the structure of laboratory experiments - a change that is predicted by game theory to make no difference in outcomes-has repeatedly had major impacts on behavior and outcomes. Simply enabling subjects to engage in face-to-face communication between decision rounds changes the decisions made so that subjects approach socially optimal harvesting levels rather than severely overharvesting the commons. In the face-to-face discussions, subjects tend to discuss what they all should do and build norms (U6) to encourage conformance. And, given an opportunity, subjects are likely to punish those who overharvest and develop their own rules to change the structure and improve outcomes (Ostrom and Nagendra 2006; Ostrom et al. 1994).

\section{The Difference between Roving Bandits and Harbor Gangs}

In addition to carefully structured common-pool experiments, social-ecological systems exist in environments that approximate the assumptions made by Hardin. Berkes et al. (2006) examine the impact of roving bandits - fishing fleets that target valuable marine species in coastal waters, deplete local stocks, and then move on to exploit stocks located in other regions. Drawing on the work of Olson (2000), who developed the concept of roving bandits, Berkes and colleagues characterize the problem: "Roving banditry is different from most commons dilemmas in that a 
new dynamic has arisen in the globalized world: New markets can develop so rapidly that the speed of resource exploitation often overwhelms the ability of local institutions to respond" (p. 1557).

These settings come very close to meeting the five conditions that Hardin specified: (1) no governance system is present (no GS); (2) no human investments have been made to improve the productivity of the resource system (the ocean) (no RS4); (3) the mobile resource units (RU1; the fish captured by a fishing boat) become the private property of the boat owner; (4) a sufficient number of fishing boats, given the size of the local fishery, harvest enough fish to destroy that local stock of fish (large U1); and (5) the individual owners of fishing vessels make decisions independently without any local organization or established norms (no U5 or U6). The only slight difference in assumptions is the third assumption related to the basis for establishing ownership of the resource units (capture as contrasted to long-term ownership).

Solving the problem of roving bandits for mobile ocean fisheries is more challenging than the successful efforts of a wide diversity of locally designed property-rights systems that have been documented for many types of resource systems harvested by users living nearby (Basurto 2005; Meinzen-Dick et al. 2002; NRC 2002, 2005; see also the Digital Library of the Commons for extensive citations, http://dlc.dlib.indiana.edu/). Berkes and colleagues (2006) point to the need for multilevel governance institutions operating from local to international levels (see also Cash et al. 2006; Crowder et al. 2006; Wilson et al. 1999; Young 2002; Young et al. 2006). They conclude that

no single approach can solve problems emerging from globalization and sequential exploitation. But the various approaches used together can slow down the roving bandit effects, and can replace destructive incentives with a resource rights framework that mobilizes environmental stewardship, i.e., one that builds the self-interested, conserving feedback that comes from attachment to place (Berkes et al. 2006: 1558).

In contrast to the roving bandit problem, Acheson, Wilson, and colleagues (Acheson 2003; Acheson et al. 1998; Wilson et al. 1994) have documented how the lobster fishermen of Maine recovered from a major crash of the lobster stock in their coastal waters during the 1920s and 1930s to experiment with a diversity of ingenious rules and norms well fitted to important attributes of the relevant resource units - the lobsters - and how fishermen were organized within the harbors where they lived and berthed their boats.

While the contemporary roving bandits of international waters simply move on after they have destroyed a stock (including the green sea urchins which were rapidly wiped out from the Maine shore in the 1980s for export to the Japanese market), the lobster fishers of Maine have lived in shoreline communities for many generations (U3), have deep roots in their communities (U4) and local leadership (U5), have developed norms of trustworthiness and reciprocity with those with whom they have close interactions (U6), and have gained effective knowledge about 
the resource system and resource units they are using (U7) to evolve an ever more valuable local fishery, with sales of Maine lobster totaling \$186.1 million in 2000 (Acheson 2003: 13). ${ }^{6}$

The biological attributes of lobsters (the RU) have enabled the state government of Maine and the lobster fishers, to develop harvesting rules and norms that have greatly contributed to the recuperation of the stock as documented by the Maine Department of Fisheries (Dietz et al. 2003: 1907, Fig. 1). Lobsters are slow growing but highly productive after reaching maturity at around seven years with an expected lifespan of up to 100 years. They are somewhat mobile but stay within a relatively close range of where their eggs hatch. Further, they are not killed when the traps in which they are lured are pulled up to the surface. Fishers sort through the catch and can safely return to the sea lobsters caught in the trap that are below and above a defined size as well as any "berried" female lobsters (easily identified by the hundreds of eggs extruded on their bellies).

As Wilson et al. (2007), however, clearly demonstrate with an agent-based classifier model, local trap-fishers may evolve any of several harvesting strategies, some of which are highly exploitative, depending on the specific combination of attributes assumed in the model. The eventual success of the Maine lobster fishery is consequently due to the congruence of multiple factors beyond the simple fact that the fishers live nearby. Returning to the history of this case (Acheson 2003: 80-90), the State of Maine initially made it illegal to harvest egg-bearing female lobsters in the $1870 \mathrm{~s}$ - a formal law that was not effective, as many fishers simply scrubbed the eggs off berried females and sold them easily. In an effort to encourage the owners of lobster pounds not to harvest berried females, the State established a fund to buy back bearing-age females from pound owners. After selling the berried females to a warden, the warden would punch a hole in the lobster tail. Any dealer or fisher caught selling lobsters with these punched holes could be prosecuted. In 1948, the law was changed to make it illegal to sell a lobster marked with a $\mathrm{V}$-notch (that lasted 2 or possibly 3 molts) rather than a simple hole. A reliable signal was created that could easily be monitored.

Soon thereafter, lobster fishers began voluntarily to V-notch some of the berried lobsters caught in their traps as a way of marking a bearing-age female and to refrain from selling a Vnotched lobster marked by another fisher. Common understanding and use of the norm grew over time and is now widely practiced (Ibid.). The widespread use of V-notching helps to solve a core problem identified in the theoretical literature on collective action of establishing reliable signals to enhance reciprocity in collective efforts (Axelrod 1997; Ostrom 1998). How can one fisher, who is trying to cooperate to enhance long-run productivity, increase the probability that other fishers will not simply harvest the female lobster he returns to the sea?

\footnotetext{
${ }^{6}$ That the lobster fishery has become more of a monoculture exposes it to the threat of an epidemic among the lobster that could generate an unexpected collapse at some future date (Carpenter, personal communication, August 1, 2006).
} 
This reciprocity norm would not be effective if in addition to the attributes of the resource users (U) described above, lobsters (RU) could not be safely returned to the sea (RU2), if most lobsters initially caught in one harbor migrated to distant harbors (RU1-a), or if the V-notch disappeared rapidly (RU6-b). A fourth important condition is that resource users are informally affiliated with others who fish from the same harbor - called a "harbor gang" by Acheson (2003: 21 ), not meaning to connate a criminal group but rather a name for a close group of fishers coming from the same harbor. Fishers living in each harbor have self-defined the outer boundaries of their territory over time. Wilson et al. (2007) demonstrate that territoriality is unlikely to evolve spontaneously in a multiagent model of a trap fishery unless fishers can potentially engage in trap cutting (a sanctioning mechanism) and retain memories of such bad events (as well as where they had good harvests and pleasant reciprocity). Self-organized monitoring and enforcement has repeatedly played an important role in explaining successful efforts at collective action (Cardenas et al. 2000; Casari and Plott 2003; Ostrom et al. 1994; Ostrom and Nagendra 2006).

\section{Distinctive Markings of Resource Units and Property-Rights Systems}

While distinctive markings of a resource unit (RU6) are not discussed in the theoretical literature, they are frequently used as an important attribute of resource units in constructing effective property-rights systems (GS4). ${ }^{7}$ Pastoralists through the ages have claimed ownership of their animals by their natural distinctive markings when the number of animals involved is relatively small and individual units are easy to identify (RU6-a). Diverse property-rights systems make use of artificial markings of resource units (RU6-b) as ways of identifying private property or resource units that need protection. Branding became a method for giving a large number of cattle a distinctive marking in the "wild west" where cattleowners' associations developed relatively large-scale governance systems involving an annual roundup and assignment of specific brands to the owners of cattle. The $\mathrm{V}$-notch marking does not assign ownership. Rather, it is a mechanism to mark an individual resource unit as valuable for the long-term sustainability of the resource system.

\footnotetext{
${ }^{7}$ McGrath et al. (2006) distinguish between fish and cattle in their study of fishing and grazing agreements on the floodplains of the lower Amazon. Cattle are more likely to be used to generate long-term income and may be a form of savings while fish are consumed immediately. They also point out that cattle are terrestrial. Thus, it is feasible to monitor and control their location easily. Since fish are aquatic it is very difficult to control their location. These key differences in biological attributes make it easy to secure property rights to one type of resource unit but not to the other. The authors also discuss a new monitoring method for pirarucu fish (Arapaimo gigas), given their specific biological attributes. These fish are very big with relatively distinctive markings. They rise to the surface in a way that has made it recently possible to count the fish. A monitoring system has been developed by the Mamiraua Sustainable Development Reserve in Brazil for counting these fish. Local fishers are being taught how to keep a good record of the number of fish in a flood-plain pond. This technological breakthrough in identifying the number of fish in a pond may facilitate the development of new rules related to the management of these resource systems that could not have been developed earlier.
} 
The territorial organization of lobster fishers in Maine takes advantage of the second major aspect of decomposability - the potential organization and governance of SESs at small to ever larger spatial scales (GS). Given the tradition of local governance in Maine, local communities have considerable authority to develop their own rules and norms related to many aspects of local community living. The lobster fishers of Maine have had considerable autonomy to develop and experiment with their own rules related to who fishes out of which harbor, when the fishing season opens or closes, size limits, V-notch rules, and other local rules. In light of the exchange of information among localities, harbor organizations have learned about and adopted more effective rules that have then been backed by the state of Maine, which is now experimenting with the creation of fishing zones across the state.

Those conditions related to autonomy in making rules were also present when the green sea urchins were overexploited, but the fishers in this instance were not local (U2), did not share norms related to harvest levels and practices (U6), and rapidly exploited the stocks (O1) to sell for export (S5) before local fishers or officials (U5) took much note of the overharvesting. Lobster stocks have been sequentially overharvested in other locations where resource user characteristics differ (have not lived in the same harbor for generations, no strong local leaders, no local norms, and little autonomy to make their own local rules) (Huitric 2005). A major factor in converting roving bandits into effectively organized local groups is finding ways of converting the short time horizon of the harvesters into one that takes a longer time horizon into account related to the conditions of the resource units in a particular resource system and generating useful information about the strategies of other fishers.

\section{Multiple Methods for Analyzing Complex Nested Systems}

Hopefully, a recognition of the decomposability of the conceptual knowledge system needed for analyzing linked SESs at multiple spatial scales will help reduce the tensions that exist among advocates of a single method for studying SESs. Those who undertake abstract analytical models have to keep their analysis to a simple set of variables, or they cannot find analytical solutions. Are the assumptions of a model characteristic of all SESs? Or, does a scholar self-consciously model an important type of system with broadly relevant but specific attributes? What analytical differences result when one dips down a conceptual level and changes one or more core assumptions? Hardin's (1968) original set of assumptions are quite robust when it comes to predicting the outcomes of a system of roving bandits but are inappropriately applied to the inshore Maine lobster fisheries (and many other self-governed SESs).

Those researchers who prefer case studies sometimes presume that the third- or fourth-tier variables observed in their studies are present in most other broadly similar SESs. When scholars suggest that a particular variable is important, other researchers sometimes respond, "Not in my case!" with the implication that the variable would not be important elsewhere. The concept of nested tiers of variables that interactively affect how other variables help or do not help to 
explain outcomes is a challenge to the way many scholars approach theory and explanation. Scholars who prefer to collect large samples and use multiple regression or similar statistical techniques are initially horrified when a large set of variables is listed, given the cost of obtaining reliable indicators of the same variable across cultural settings. Mistakenly, they presume that all of these variables need to be measured and included in future research. Instead, third-, fourth-, and fifth-tier variables are relevant only when they are subcomponents of a relevant second-tier variable and affect interactions and outcomes.

Scholars who examine the patterns of interactions (I) and outcomes $(\mathrm{O})$ for a large number of resource systems (RS) by undertaking meta-analyses of the case studies written by other scholars or by undertaking new research find that they must include a large number of variables like those identified in Tables 1 and 2 (and future tables to be developed soon) to explain outcomes. One of the frustrating aspects of conducting meta-analyses is the large number of individual case studies that must be read and given initial codes in order to find a reasonable set of cases with specific information about the core variables identified in Figure 1 and Tables 1 and 2.

Pagdee et al. (2006), for example, identified 110 case studies related to forest management involving some aspects of local participation. Many of these studies did not have sufficient information about outcomes and about the resource system, the resource users, and the governance system to be able to determine the factors associated with observed outcomes. Pagdee and colleagues were able to conduct their meta-analysis based on only 31 of the 110 original case studies identified.

The CPR database developed by colleagues at Indiana University screened a very large number of cases before identifying a set of 47 irrigation systems with sufficient and reliable data to analyze (out of 450 documents screened) (Tang 1994) and 33 organized groups of fishers (also after screening several hundred documents) (Schlager 1994). Without a common taxonomy of core variables, research conducted by scholars from multiple disciplines tend to focus on the variables of major interest to their own disciplines without measuring, controlling for, or even thinking about other variables that might account for the patterns of interactions and outcomes observed (Poteete and Ostrom 2006). In their effort to assess the effectiveness of diverse conservation strategies, Brooks et al. (2006) also conducted a meta-analysis of empirical studies and found that researchers measured different variables rather than testing a common set of factors potentially associated with success. Agrawal and Redford (2006) present a powerful critique of the lack of consistent measures across studies of social-ecological systems.

Thus, a generally accepted multitier nested framework will help scholars identify at what conceptual level their research is located and how research undertaken at multiple conceptual levels using diverse methods complements, rather than competes with, research using other methods and other levels. Without such a framework further unnecessary "wars" over research methods will continue. Hopefully, the framework presented herein will stimulate further development of it so as to gain greater cumulative knowledge about the complex systems we are 
studying. By building and using a multitier conceptual framework, scholars can draw on all of the above methods as well as newer modeling techniques such as agent-based models (Axelrod 2006; Janssen 2002; Janssen and Ostrom 2006), use of remotely sensed data combined with onthe-ground data (Brondízio et al. 1996; Moran and Ostrom 2005; Ostrom and Nagendra 2006), and statistical techniques, such as qualitative conceptual analysis (Ragin 1987, 2000; Rudel 2005).

\section{A Digression on Patchy Environments}

A brief digression may illustrate how research findings from diverse settings and multiple methods can increase our long-term understanding of complex SESs. When I analyzed a large number of case studies of CPRs during the last half of the 1980s, I focused on a large set of smaller CPRs whose long utilization by humans had been well documented. In light of intensely studying the robust systems that had sustained themselves over long periods, as contrasted to systems that had collapsed, I posited a series of eight design principles that distinguished between the robust and collapsed systems. One of these principles related to clearly defining the boundaries of the resource system and of users who have rights to withdraw resource units from the resource system (Ostrom 1990). Not only was this design principle supported by the original cases studied and by other scholars (Berkes 2007; Meinzen-Dick 2007; Trawick 2001, 2003), but I was able to use theoretical models to show how trust and reciprocity could be built more effectively in such environments, where individuals were likely to engage in repeated interactions (Ostrom 1998, 1999).

Scholars who have studied African pastoral systems characterized by substantial spatial and temporal variability in rainfall (RS7) and thus in forage availability (RU7-a) and mobile resource units (RU1-a) have questioned whether clearly defined boundaries are conducive to effective resource governance in these erratic settings or whether they make common-property institutions too exclusive (Goodhue and McCarthy 2000; Haro et al. 2005; McCarthy et al. 2004). These scholars are pointing out the challenge of devising long-term workable governance systems in patchy environments. They have mistakenly interpreted the concept of "clearly defined" to be the same as rigidly defined. Successful pastoral groups in highly uncertain environments have developed ingenious methods for moving herds over long distances (Agrawal 1998; Mwangi 2007). The pastoralists are able to negotiate among themselves where to graze in an ever changing landscape because there is a common understanding of who has primary, secondary, or tertiary rights to graze in a broad zone, depending on forage availability and outcomes of negotiations.

Pastoralists in Australia also face severe variability of rainfall (Walker and Janssen 2002) and, over time, have developed an institution called "agistment." Agistment is a commercial contract between private owners of cattle and land. In an era of resource deficiency in one region of Australia, an owner can contract with another owner located far away where more forage is 
available to ship cattle to be pastured and cared for temporarily. In this instance, owners are designing new boundary rules that enable them to develop short-term mechanisms to offset temporal and spatial patchiness of the resource.

In their effort to understand this novel institutional arrangement, McAllister et al. (2006) first developed a game theoretical model of the social dilemma facing pastoralists who do not know one another and may not have repeated opportunities for gaining trust and reciprocity. Based on the initial theoretical model and on in-depth interviews with pastoralists from northeastern Queensland, the researchers then developed an agent-based model placing individual owners on a computerized biophysical landscape represented as a $20 \times 20$ grid. The grid represented 400 pastoral properties owned by individual private owners whose land was affected by spatially distributed rain events that decreased or increased the productivity of the land. With this model, they could vary the spatial variation of rainfall in the model and examine the resulting levels of trust and cooperative bargains undertaken by owners located far away from one another. They found that agistment contracts across varying distances help pastoralists cooperate to protect themselves from significant losses under high levels of spatial variation.

Thus, careful modeling of the diverse processes occurring in a complex SES where private tenure existed related to land, but where high levels of spatial and temporal rainfall variability also occurred, enabled researchers to diagnose the problem and how agistment contracts help pastoralists protect themselves against risk. A combination of methods enabled scholars, who themselves were located at a far distance, to work out a better understanding of the diverse ways in which the boundaries of property rights to a flow from a resource may be defined.

\section{Decomposability and Nested Governance Systems}

The two-person, private agistment contract is a very small governance system for helping to achieve long-term sustainability over a vast expanse of land. Such private contracts are, of course, embedded in the legal system of the localities, regions, and country in which they take place. An owner knows that if he or she reneges on key aspects of the contract (failing to feed the cattle sent or not protecting their safety, for example), there is a risk of being taken to court. Or failure might be disseminated by a cattleowners' organization so as to reduce the likelihood of future commercially attractive contracts. Thus, this two-person contract is nested in several layers of larger public and private governance systems.

The roving bandits of ocean fisheries discussed above include many more participants, but so far they have also escaped from being embedded in any local, national, or international governance systems. It is hard to design an effective, let alone optimal, way of solving the roving bandit problem. As Berkes et al. (2006) stress, however, it is likely that no single approach at one and only one spatial scale will solve problems resulting from globalization and sequential exploitation. Berkes and colleagues recommend that various approaches be used together at multiple scales - in the sense of decomposable systems - to slowly evolve a complex, multilevel 
Sustainable Social-Ecological Systems: An Impossibility?

Elinor Ostrom

governance system that enhances environmental stewardship. That is a challenge for all of us interested in moving beyond panaceas.

\section{Conclusion}

In order to achieve sustainable governance of SESs, scholars and policy analysts need a better understanding of decomposable, multitier governance systems derived from systematic research that bridges the contemporary chasm separating biophysical and social science research. Further, as we have learned from medical research, prescribed cures frequently have unanticipated effects, depending on which combination of remedies is used. Policy analysts must begin to study and record the unintended effects of particular policy interventions so dangerous combinations of policies devised at diverse tiers or due to particular aspects of a resource system and resource units can be self-consciously avoided. Just as there is no cure-all that works in all settings, there is no ideal "entry point" for carrying out rigorous, useful research on linked SESs. The entry point for conducting research on SESs depends on the question of major interest to the researcher, user, or policy maker. For some questions, the appropriate focal system is the broader Social, Economic, and Political Setting (S), where one compares these broader settings over time and across space as they impact on the problem-solving capability of Resource Users (RU) and the officials in a Governance System (GS) as their interactions affect a Resource System (RS) and Resource Units (RU). When one is examining a problem within a particular setting S (e.g., all RSs in a single country at one historical period) or where the RSs are located in isolated areas with weak impacts from the broader S, one may enter analysis by identifying a particular type of RS (e.g., forests in mountainous regions). Or one may start with a particular type of RS or GS and ask how these function in diverse, broader settings by beginning with a second- or third-tier variable and moving up to include first-tier variables to help explain the differences in outcomes. $^{8}$

We must keep in mind that broader as well as more specific variables may have an important role in explaining observed outcomes depending on the question and resulting processes being examined. Identifying a clear question must always be the first step in analyzing linked social-ecological systems. Once we identify a good entry point for examining a particular question, we can then embed it in an analysis using variables from multiple tiers. Or, one may start as Berkes (2007) has done by asking how to establish more effective conservation projects with active (as contrasted to nominal) participation. In his analysis, he uses the theoretical developments of complex adaptive systems to avoid a blueprint approach while advocating a

\footnotetext{
${ }^{8}$ Carlsson and Berkes (2005: 65) outline a series of steps for conducting policy analysis of co-management systems: "This kind of research approach might employ the steps of (1) defining the social-ecological system under focus; (2) mapping the essential management tasks and problems to be solved; (3) clarifying the participants in the problemsolving processes; (4) analyzing linkages in the system, in particular across levels of organization and across geographical space; (5) evaluating capacity-building needs for enhancing the skills and capabilities of people and institutions at various levels; and (6) prescribing ways to improve policy making and problem-solving."
} 
Sustainable Social-Ecological Systems: An Impossibility?

Elinor Ostrom

conceptual approach closely related to the framework outlined above for diagnosing diverse conservation efforts. The framework presented in this paper will obviously need further development. Hopefully, cumulative use of the framework to undertake better designed research, analysis, and policy proposals will reduce the tendency to prescribe simple panaceas for solving the diversity of problems facing linked social-ecological systems in the coming years.

\section{Acknowledgments}

I gratefully thank James Acheson, Marty Anderies, Krister Andersson, Fikret Berkes, Monique Borgerhoff Mulder, Eduardo Brondízio, Buz Brock, Steve Carpenter, Daniel Cole, Susan Fitzpatrick, Gustavo Garcia-Lopez, Miriam Huitric, Marco Janssen, Prakash Kashwan, Bobbi Low, Ryan McAllister, Michael McGinnis, Keith M. Moore, Thomas Moore, Lauren Morris MacLean, Harini Nagendra, Scott Page, Charles Perrings, Maja Schlueter, Michael Schoon, Carl Simon, Kerry Smith, Paul Stern, Emil Uddhammar, James Wilson, Tracy Yandle, and graduate students in Y673 for very helpful comments on earlier drafts and Joanna Broderick for her excellent editing. The research from which this paper is drawn was funded by the National Science Foundation (grant SES0083511) and support from the Ford Foundation and the MacArthur Foundation.

\section{References}

Acheson, James. 2003. Capturing the Commons: Devising Institution to Manage the Maine Lobster Industry. New Haven, CT: University Press of New England.

Acheson, James M., James A. Wilson, and Robert S. Steneck. 1998. Managing Chaotic Fisheries. In Linking Social and Ecological Systems: Management Practices and Social Mechanisms for Building Resilience, ed. Fikret Berkes and Carl Folke, 390-413. New York: Cambridge University Press.

Ackoff, Russell L. 2001. Fundamentalism and Panaceas. Systemic Practice and Action Research 14(1):310.

Adams, W. M., and A. Hulme. 2001. If Community Conservation is the Answer in Africa, What is the Question? Oryx 35(3):193-200.

Agrawal, Arun. 1998. Greener Pastures: Politics, Markets, and Community among a Migrant Pastoral People. Durham, NC: Duke University Press.

Agrawal, Arun. 2002. Common Resources and Institutional Sustainability. In Drama of the Commons, ed. Committee on the Human Dimensions of Global Change, National Research Council, 41-86. Washington, DC: National Academies Press. URL: http://www.nap.edu/books/0309082501/html/.

Agrawal, Arun, and Kent Redford. 2006. Poverty, Development and Biodiversity Conservation: Shooting in the Dark? WCS Working Paper No. 26. New York: Wildlife Conservation Society (WCS). URL: http://www.wcs.org/media/file/wcswp26.pdf.

Agrawal, Arun, and Jesse Ribot. 1999. Accountability in Decentralization: A Framework with South Asian and West African Cases. The Journal of Developing Areas 33(4):295-312.

Ahl, V., and T. F. H. Allen. 1996. Hierarchy Theory: A Vision, Vocabulary, and Epistemology. New York: Columbia University Press.

Allen, T. F. H., and T. W. Hoekstra. 1992. Toward a Unified Ecology. New York, Columbia University Press.

Anderies, J. Marty, Marco Janssen, and Elinor Ostrom. 2004. A Framework to Analyze the Robustness of Social-Ecological Systems from an Institutional Perspective. Ecology and Society 9(1):18 [online]. URL: http://www.ecologyandsociety.org/vol9/iss1/art18/.

Armstrong, Claire W., and Ussif Rashid Sumaila. 2001. Optimal Allocation of TAC and the Implications of Implementing an ITQ Management System for the North-East Arctic Cod. Land Economics 77(3):350-359. 
Sustainable Social-Ecological Systems: An Impossibility?

Elinor Ostrom

Atran, Scott, Douglas Medin, Norbert Ross, Elizabeth Lynch, Valentina Vapnarsky, Edilberto Ucan Ek', John Coley, Christopher Timura, and Michael Baran. 2002. Folkecology, Cultural Epidemiology, and the Spirit of the Commons: A Garden Experiment in the Maya Lowlands, 1991-2001. Current Anthropology 43(3):421-450.

Axelrod, Robert. 1997. The Complexity of Cooperation. Princeton, NJ: Princeton University Press.

Axelrod, Robert. 2006. Agent-Based Modeling as a Bridge between Disciplines. In Handbook of Computational Economics: Agent-Based Computational Economics, vol. 2, ed. Leigh Tesfatsion and Kenneth L. Judd, 1565-1584. Amsterdam: North-Holland Imprint of Elsevier Publishers.

Axelrod, Robert, and Michael D. Cohen. 2001. Harnessing Complexity: Organizational Implications of a Scientific Frontier. Reprint edition. New York: Basic Books.

Bacho, Francis Z. L. 2004 Decentralization in a pluralist state: ethnic identity, resource conflicts and development in the East Gonja District, Ghana. Working paper. Tamale, Ghana: University of Development Studies; Department of Planning, Land Economy, and Rural Development.

Basurto, Xavier. 2005. How Locally Designed Access and Use Controls Can Prevent the Tragedy of the Commons in a Mexican Small-Scale Fishing Community. Society and Natural Resources 18:643659.

Berkes, Fikret. 2007. Community-based conservation in a globalized world. Working paper. Winnipeg: University of Manitoba, Canada.

Berkes, Fikret, Johan Colding, and Carl Folke, eds. 2003. Navigating Social-Ecological Systems: Building Resilience for Complexity and Change. Cambridge, UK: Cambridge University Press.

Berkes, Fikret, and Carl Folke, eds. 1998. Linking Social and Ecological Systems: Management Practices and Social Mechanisms for Building Resilience. Cambridge, UK: Cambridge University Press.

Berkes, Fikret, T. P. Hughes, R. S. Steneck, J. A. Wilson, D. R. Bellwood, B. Crona, C. Folke, L. H. Gunderson, H. M. Leslie, J. Norberg, M. Nyström, P. Olsson, H. Österblom, M. Scheffer, and B. Worm. 2006. Globalization, Roving Bandits, and Marine Resources. Science 311(March 17):15571558 .

Blomquist, William, Edella Schlager, and Tanya Heikkila. 2004. Common Waters, Diverging Streams: Linking Institutions and Water Management in Arizona, California, and Colorado. Washington, DC: Resources for the Future.

Brock, William A., and Stephen R. Carpenter. 2007. Panacea traps, escape routes and diversification of environmental policy. Working paper. Madison: University of Wisconsin.

Brondízio, Eduardo, Emilio F. Moran, Paul Mausel, and You Wu, 1996. Land Cover in the Amazon Estuary: Linking of the Thematic Mapper with Botanical and Historical Data. Photogrammetric Engineering and Remote Sensing 62:921-929.

Brooks, J. S., M. A. Franzen, C. M. Holmes, M. Grote, and M. Bogerhoff-Mulder. 2006. Testing Hypotheses for the Success of Different Conservation Strategies. Conservation Biology 20(2):1528 1538.

Camerer, Colin F. 2003. Behavioral Game Theory: Experiments in Strategic Interaction. Princeton, NJ: Princeton University Press.

Cardenas, Juan-Camilo, and Elinor Ostrom. 2004. What Do People Bring Into the Game? Experiments in the Field about Cooperation in the Commons. Agricultural Systems 82(3):307-326.

Cardenas, Juan-Camilo, John Stranlund, and Cleve Willis. 2000. Local Environmental Control and Institutional Crowding-Out. World Development 28(10):1719-1733.

Carlsson, Lars, and Fikret Berkes. 2005. Co-Management: Concepts and Methodological Implications. Journal of Environmental Management 75:65-76.

Carpenter, Stephen R., and William Brock. 2003. Spatial Complexity, Resilience, and Policy Diversity: Fishing on Lake-Rich Landscapes. Ecology and Society 84(6):493-502.

Carpenter, Stephen R., and William A. Brock. 2004. Spatial Complexity, Resilience, and Policy Diversity: Fishing on Lake-Rich Landscapes. Ecology and Society 9(1):8 [online] URL: http://www/ecologyandsociety.org/vo19/iss1/art8. 
Sustainable Social-Ecological Systems: An Impossibility?

Elinor Ostrom

Carpenter, Stephen R., and Lance H. Gunderson. 2001. Coping with Collapse: Ecological and Social Dynamics in Ecosystem Management. BioScience 51(6):451-457.

Casari, Marco, and Charles R. Plott. 2003. Decentralized Management of Common Property Resources: Experiments with a Centuries-Old Institution. Journal of Economic Behavior and Organization 51:217-247.

Cash, David W., W. Neil Adger, Fikret Berkes, Po Garden, Louis Lebel, Per Olsson, Lowell Pritchard, and Oran Young. 2006. Scale and Cross-Scale Dynamics: Governance and Information in a MultiScale World. Ecology and Society 11(2):8 [online]. URL:

http://www.ecologyandsociety.org/vol11/iss2/art8/.

Chapin, Stuart F. III, Amy Lovecraft, Erika S. Zavaleta, Joanna Nelson, Martin D. Robards, Gary P. Kofinas, Sarah F. Trainor, Garry D. Peterson, Henry P. Huntington, and Rosamond L. Naylor. 2006. Policy Strategies to Address Sustainability of Alaskan Boreal Forests in Response to a Directionally Changing Climate. Proceedings of the National Academy of Sciences (USA) 103(45):16637-16643.

Clark, Colin. 2006a. Fisheries Bioeconomics: Why is it so Misunderstood? Population Ecology 48(2):9598.

Clark, Colin. 2006b. Worldwide Crisis in Fisheries: The Use and Misuse of Models. Cambridge, UK: Cambridge University Press.

Clark, William C., and N. M Dickson. 2003. Sustainable Science and Environmental Research Program. Proceedings of the National Academy of Sciences (USA) 100(14):8059-8061.

Clark, William C., Robert W. Kates, Alan H. McGowan, and Timothy O. Riordan. 2005. Science and Policy for Sustainable Development. Environment 47(1):2.

Conley, Alexander, and Margaret A. Moote. 2003. Evaluating Collaborative Natural Resource Management. Society and Natural Resources 16:371-386.

Crowder, L. B., G. Osherenko, O. R. Young, S. Airamé, E. A. Norse, N. Baron, J. C. Day, F. Douvere, C. N. Ehler, B. S. Halpern, S. J. Langdon, K. L. McLeod, J. C. Ogden, R. E. Peach, A. A. Rosenberg, and J. A. Wilson. 2006. Resolving Mismatches in U.S. Ocean Governance. Science 313(August 4):617-618.

Dasgupta, Partha, and Karl-Göran Mäler. 1995. Poverty, Institutions, and the Environmental ResourceBase. In Handbook of Development Economics, vol. 3, ed. J. Behrman and T. N. Srinavasan, 271463. Amsterdam: Elsevier.

Demsetz, Harold. 1967. Toward a Theory of Property Rights. American Economic Review 57:347-359.

Dietz, Tom, Elinor Ostrom, and Paul C. Stern. 2003. The Struggle to Govern the Commons. Science 302(December 12):1907-1912. Article available at http://www.sciencemag.org/cgi/reprint/302/5652/1907.pdf and CIPEC supplemental material available at http://www.sciencemag.org/cgi/data/302/5652/1907/DC1/1 (subscription required).

Doyle, Alister. 2006. Double Forest Area under Local Control, Group Says. Reuters Online, May 3.

Eggertsson, Thrainn. 2005. Imperfect Institutions: Possibilities and Limits of Reform. Ann Arbor: University of Michigan Press.

Epstein, Richard. 1997. Simple Rules for a Complex World. Cambridge, MA: Harvard University Press. Fitzpatrick, Daniel. 2006. Evolution and Chaos in Property Rights Systems: The Third World Tragedy of Contested Access. Yale Law Journal 115:996-1048.

Geist, Helmut J., and Eric F. Lambin. 2001. What Drives Tropical Deforestation? A Meta-Analysis of Proximate and Underlying Causes of Deforestation Based on Subnational Case Study Evidence. LUCC Report Series, No. 4. Louvain la Neuve, Belgium: LUCC International Project Office, International Geosphere-Biosphere Programme. URL: http://www.geo.ucl.ac.be/LUCC/pdf/LUCC\%20Report\%20-\%20Screen.pdf.

Gelcich, Stafan, Gareth Edwards-Jones, Michel J. Kaiser, and Juan C. Castilla. 2006. Co-Management Policy Can Reduce Resilience in Traditionally Managed Marine Ecosystems. Ecosystems 9:951-966. 
Sustainable Social-Ecological Systems: An Impossibility?

Elinor Ostrom

Goodhue, R. E., and Nancy McCarthy. 2000. Fuzzy Access: Modeling Grazing Rights in Sub-Saharan Africa. In Property Rights, Risk, and Livestock Development in Africa, ed. Nancy McCarthy, Brent Swallow, Michael Kirk, and Peter Hazell, 191-210. Washington, DC: International Food Policy Research Institute.

Groves, Theodore, and John Ledyard. 1977. Optimal Allocation of Public Goods: A Solution to the "Free Rider" Problem. Econometrica 45:783-809.

Gunderson, Lance H., and C. S. Holling. 2002. Panarchy. Understanding Transformation in Human and Natural Systems. Washington, DC: Island Press.

Hansen, Zeynep K., and Gary D. Libecap. 2004. The Allocation of Property Rights to Land: US Land Policy and Farm Failure in the Northern Great Plains. Explorations in Economic History 41:103129.

Haro, Guyo O., Godana H. Doyo, and John G. McPeak. 2005. Linkages between Community, Environmental, and Conflict Management: Experiences from Northern Kenya. World Development. 33(2):285-299.

Hardin, Garrett. 1968. The Tragedy of the Commons. Science 162(December 13):1243-1248.

Higgs, Robert. 1996. Legally Induced Technical Regress in the Washington Salmon Fishery. In Empirical Studies in Institutional Change, ed. Lee J. Alston, Thrainn Eggertsson, and Douglass C. North, 247279. New York: Cambridge University Press.

Holling, C. S. 1978. Adaptive Environmental Assessment and Management. London: Wiley.

Holling, C. S., Fikret Berkes, and Carl Folke. 1998. Science, Sustainability, and Resource Management. In Linking Social and Ecological Systems: Management Practices and Social Mechanisms for Building Resilience, ed. Fikret Berkes and Carl Folke, 342-362. Cambridge, UK: Cambridge University Press.

Holmes, Oliver Wendell. 1988. Medical Essay, 1842-1882. Boston: Houghton Mifflin.

Huitric, Miriam. 2005. Lobster and Conch Fisheries of Belize: A History of Sequential Exploitation. Ecology and Society 10(1):21 [online]. URL: http://www.ecologyandsociety.org/vol10/iss1/art21/.

Janssen, Marco A., ed. 2002. Complexity and Ecosystem Management. Cheltenham, UK: Edward Elgar.

Janssen, Marco A., Robert L. Goldstone, Filippo Menczer, and Elinor Ostrom. 2006. Effect of Rule Choice in Dynamic Interactive Spatial Commons. CIPEC Working Paper CWP-06-04. Bloomington: Center for the Study of Institutions, Population, and Environmental Change (CIPEC), Indiana University.

Janssen, Marco A., and Elinor Ostrom. 2006. Governing Social-Ecological Systems. In Handbook of Computational Economics: Agent-Based Computational Economics, vol. 2, ed. Leigh Tesfatsion and Kenneth L. Judd, 1465-1509. Amsterdam: North-Holland Imprint of Elsevier Publishers.

John, DeWitt. 2006. Top-Down, Grassroots, and Civic Environmentalism: Three Way to Protect Ecosystems. Frontiers in Ecology and the Environment 4 (1):45-46.

Josse, C., G. Navarro, P. Comer, R. Evans, D. Faber-Langendoen, M. Fellows, G. Kittel, S. Menard, M. Pyne, M. Reid, K. Schulz, K. Snow, and J. Teague. 2003. Ecological Systems of Latin America and the Caribbean: A Working Classification of Terrestrial Systems. Arlington, VA: NatureServe. URL: http://www.natureserve.org/library/LACEcologicalSystems.pdf.

Kaiser, Jocelyn. 2006. A One-Size-Fits-All Flu Vaccine? Science 312(April 21):380-382.

Kaimowitz, David, and Arild Angelsen. 1998. Economic Models of Tropical Deforestation: A Review. Bogor, Indonesia: Center for International Forestry Research.

Kikeri Sunita, and John Nellis. 2004. An Assessment of Privatization. World Bank Research Observer 19(1):87-118.

Koestler, Arthur. 1973. The Tree and the Candle. In Unity through Diversity, ed. William Gray and Nicholas D. Rizzo, 287-314. New York: Gordon and Breach Science Publishers.

Korten, David M. 1980. Community Organization and Rural Development: A Learning Process Approach. Public Administration Review 40(5):480-511. 
Sustainable Social-Ecological Systems: An Impossibility?

Elinor Ostrom

Lambin, Eric F., Billie Lee Turner II, Helmut J. Geist, Samuel B. Agbola, Arild Angelsen, John W. Bruce, Oliver T. Coomes, Rodolfo Dirzo, Günther Fischer, Carl Folke, P. S. George, Katherine Homewood, Jacques Imbernon, Rik Leemans, Xiubin Li, Emilio F. Moran, X. Michael Mortimore, P. S. Ramakrishna, John F. Richards, Helle Skånes, Glenn D. Stone, Uno Svedin, Tom A. Veldkamp, Coleen Vogel, and Jianchu Xu. 2001. The Causes of Land-use and Land Cover Change: Moving Beyond the Myths. Global Environmental Change: Human and Policy Dimensions 11 (4):261-269.

Lee, Kai N. 1993. Compass and Gyroscope: Integrating Science and Politics for the Environment. Washington, DC: Island Press.

Levin, Simon. 1995. Ecosystems and the Biosphere as Complex Adaptive Systems. Ecosystems 1:431436.

Levin, Simon. 1999. Fragile Dominion: Complexity and the Commons. Reading, MA: Perseus Books. Libecap, Gary D. 1989. Contracting for Property Rights. Cambridge, UK: Cambridge University Press.

Libecap, Gary D. 2006. Assigning Property Rights in the Common Pool: Implications of the Prevalence of First Possession Rules. Presentation at "Sharing the Fish 06" Conference, Fremantle, WA, Australia, February 26-March 2.

Libecap, Gary D., and Steven N. Wiggins. 1985. The Influence of Private Contractual Failure on Regulation: The Case of Oil Field Unitization. Journal of Political Economy 93(4):690-714.

Lovejoy, Thomas E. 2006. Protected Areas: A Prism for a Changing World. Trends in Ecology and Evolution 21(June):329-333.

Low, Bobbi, Elinor Ostrom, Carl Simon, and James Wilson. 2003. Redundancy and Diversity: Do They Influence Optimal Management? In Navigating Social-Ecological Systems, ed. Fikret Berkes, Johan Colding, and Carl Folke, 83-114. New York: Cambridge University Press.

Marshall, Graham R. 2005. Economics for Collaborative Environmental Management. Renegotiating the Commons. London: Earthscan.

McAllister, Ryan R. J., Iain J. Gordon, Marco A. Janssen, and Nick Abel. 2006. Pastoralists' Responses To Variation of Rangeland Resources in Time and Space. Ecological Applications 16(2):572-583.

McCarthy, Nancy, with Celine Dutilly-Diane, Boureima Drabo, Abdul Kamara, and Jean-Paul Vanderlinden. 2004. Managing Resources in Erratic Environments: An Analysis of Pastoralist Systems in Ethiopia, Niger, and Burkina Faso. Washington, DC: International Food Policy Research Institute. URL: http://www.ifpri.org/pubs/abstract/abstr135.htm.

McGinnis, Michael, and John Williams. 2001. Compound Dilemmas: Democracy, Collective Action and Superpower Rivalry. Ann Arbor: University of Michigan Press,

McGrath, David G., O. T. Almeida, and F. D. Merry. 2006. The Influence of Community Management Agreements on Household Economic Strategies: Cattle Grazing and Fishing Agreements on the Lower Amazon Floodplain. Presented at the meetings of the International Association for the Study of Common Property in Bali, Indonesia, June.

Meinzen-Dick, Ruth. 2007. Beyond panaceas in water institutions. Working paper. Washington, DC: International Food Policy Research Institute.

Meinzen-Dick, Ruth, K. V. Raju, and Ashok Gulati. 2002. What Affects Organization and Collective Action for Managing Resources? Evidence from Canal Irrigation Systems in India. World Development 30(4):649-666.

Mitchell, Ronald B., William C. Clark, David Cash, and Nancy Dickson. 2006. Global Environmental Assessments: Information and Influence. Cambridge: MIT Press.

Montero, J. P. 2000. Optimal Design of a Phase-In Emissions Trading Program. Journal of Public Economics 75(2):273-291.

Moran, Emilio F., ed. 1995. The Comparative Analysis of Human Societies: Toward Common Standards for Data Collection and Reporting. Boulder, CO: Lynne Rienner.

Moran, Emilio F. 2006. People and Nature: An Introduction to Human Ecological Relations. Oxford, UK: Blackwell Publishing. 
Sustainable Social-Ecological Systems: An Impossibility?

Elinor Ostrom

Moran, Emilio F., and Elinor Ostrom, eds. 2005. Seeing the Forest and the Trees. Human Environment Interactions in Forest Ecosystems. Cambridge, MA: MIT Press.

Mulherin, J. Harold. 2005. Corporations, Collective Action and Corporate Governance: One Size Does Not Fit All. Public Choice 124(1-2):179-204.

Mulrow, Cynthia D., and Kathleen N. Lohr. 2001. Proof and Policy from Medical Research Evidence. Journal of Health Politics, Policy, and Law 26(2):249-266.

Mwangi, Esther. 2007. Socioeconomic Change and Land Use in Africa: The Transformation of Property Rights in Kenya's Maasailand. New York: Palgrave MacMillan.

Netting, Robert McC. 1976. What Alpine Peasants Have in Common: Observations on Communal Tenure in a Swiss Village. Human Ecology 4:135-146

Netting, Robert McC. 1981. Balancing on an Alp. Cambridge, UK: Cambridge University Press.

NRC (National Research Council). 2002. The Drama of the Commons. Committee on Human Dimensions of Global Change. Washington, DC: National Academies Press. URL: http://www.nap.edu/books/0309082501/html/.

NRC (National Research Council). 2005. Decision Making for the Environment: Social and Behavioral Science Research Priorities. Committee on the Human Dimensions of Global Change. Washington, DC: National Academies Press.

NSB (National Science Board). 1989. Loss of Biological Diversity: A Global Crisis Requiring International Solutions. Task Force on Global Biodiversity. Report NSB 89-171. Washington, DC: author.

Olson, Mancur. 2000. Power and Prosperity. New York: Basic Books.

Ostrom, Elinor. 1990. Governing the Commons: The Evolution of Institutions for Collective Action. Cambridge, UK: Cambridge University Press.

Ostrom, Elinor. 1998. A Behavioral Approach to the Rational Choice Theory of Collective Action. 1997 American Political Science Association Presidential Address American Political Science Review 92(1):1-22.

Ostrom, Elinor. 1999. Coping with Tragedies of the Commons. Annual Review of Political Science 2:493-535.

Ostrom, Elinor. 2005. Understanding Institutional Diversity. Princeton, NJ: Princeton University Press.

Ostrom, Elinor, Roy Gardner, and James Walker. 1994. Rules, Games, and Common-Pool Resources. Ann Arbor: University of Michigan Press.

Ostrom, Elinor, and Harini Nagendra. 2006. Insights on Linking Forests, Trees, and People from the Air, on the Ground, and in the Laboratory. Proceedings of the National Academy of Sciences (USA) 103(51):19224-19231.

Pagdee, Adcharaporn, Yeon-su Kim, and P. J. Daugherty. 2006. What Makes Community Forest Management Successful: A Meta-Study from Community Forests Throughout the World. Society and Natural Resources 19:33-52.

Page, Scott. 2007. The Difference: How the Power of Diversity Creates Better Groups, Firms, Schools, and Societies. Princeton, NJ: Princeton University Press.

Pearce, David. 1988. Optimal Prices for Sustainable Development. In Economics, Growth, and Sustainable Environment, ed. D. Collard, David Pearce, and D. Ulph. London: MacMillan.

Pearce, David, Anil Markandya, and Edward B. Barbier. 1989. Blueprint for a Green Economy. London: Earthscan.

Porter, Michael E., and Elizabeth Olmsted Teisberg. 2006. Redefining Health Care: Creating ValueBased Competition on Results. Boston: Harvard Business School Press.

Poteete, Amy, and Elinor Ostrom. 2004a. Heterogeneity, Group Size and Collective Action: The Role of Institutions in Forest Management. Development and Change 35(3):435-461.

Poteete, Amy, and Elinor Ostrom. 2004b. In Pursuit of Comparable Concepts and Data about Collective Action. Agricultural Systems 82(3):215-232. 
Sustainable Social-Ecological Systems: An Impossibility?

Elinor Ostrom

Poteete, Amy R. and Elinor Ostrom. 2006. Fifteen Years of Empirical Research on Collective Action in Natural Resource Management: Struggling to Build Large-N Databases Based on Qualitative Research. Working Paper W06I-25. Bloomington: Workshop in Political Theory and Policy Analysis, Indiana University.

Pritchett, Lant, and Michael Woolcock. 2003. Solutions When the Solution Is the Problem: Arraying the Disarray in Development. World Development 35(3):435-461.

Ragin, Charles. 1987. The Comparative Method: Moving Beyond Qualitative and Quantitative Strategies. Berkeley: University of California Press.

Ragin, Charles. 2000. Fuzzy-Set Social Science. Chicago: University of Chicago Press.

Rees, Judith. 1992. Markets—The Panacea for Environmental Regulation? Geoforum 23(3):383-394.

Rudel, Thomas K. 2005. Tropical Forests: Regional Paths of Destruction and Regeneration in the Late Twentieth Century. New York: Columbia University Press.

Schlager, Edella. 1994. Fishers' Institutional Responses to Common-Pool Resource Dilemmas. In Rules, Games, and Common-Pool Resources, ed. Elinor Ostrom, Roy Gardner, and James Walker, 247266. Ann Arbor: University of Michigan Press.

Schlager, Edella, William Blomquist, and Shui Yan Tang. 1994. Mobile Flows, Storage, and SelfOrganized Institutions for Governing Common-Pool Resources. Land Economics 70(3):294-317.

Scott, James C. 1998. Seeing Like a State: How Certain Schemes to Improve the Human Condition Have Failed. New Haven, CT: Yale University Press.

Silverman, W. A. 1993. Doing More Good Than Harm. Doing More Good Than Harm: The Evaluation of Health Care Intervention, ed. K.S. Warren and M. Nosteller, 5-11. New York: New York Academy of Science.

Simon, Herbert. 2000. Public Administration in Today's World of Organizations and Markets. PS: Political Science and Politics 33(4):749-756.

Smith, Robert J. 1981. Resolving the Tragedy of the Commons by Creating Private Property Rights in Wildlife. CATO Journal 1:439-468.

Tang, Shui Yan. 1994. Institutions and Performance in Irrigation Systems. In Rules, Games, and Common-Pool Resources, ed. Elinor Ostrom, Roy Gardner, and James Walker, 225-246. Ann Arbor: University of Michigan Press.

Terborgh, J. 1999. Requiem for Nature. Washington DC: Island Press.

Terborgh, J., and C. P. Schaik. 1997. Minimizing Species Loss: The Imperative of Protection. In The Land Stand: Protected Areas and the Defense of Tropical Biodiversity, ed. R. A. Krame, C. P. van Schaik and J. Johnson, 15-35. Oxford, UK: Oxford University Press.

Tietenberg, Tom. 2002. The Tradable Permits Approach to Protecting the Commons: What Have We Learned? In The Drama of the Commons, ed. Committee on the Human Dimensions of Global Change, National Research Council, 197-232. Washington, DC: National Academies Press. URL: http://www.nap.edu/books/0309082501/html/.

Tipton, C. A. 1995. Protecting Tomorrow's Harvest: Developing a National System of Individual Transferable Quotas to Conserve Ocean Resources. Virginia Environmental Law Journal 12:381421.

Trawick, Paul. 2001. Successfully Governing the Commons: Principles of Social Organization in an Andean Irrigation System. Human Ecology 29(1):1-25.

Trawick, Paul. 2003. Against the Privatization of Water: An Indigenous Model for Improving Existing Laws and Successfully Governing the Commons. World Development 31(6):977-996.

Tucker, Catherine M., J. C. Randolph, and Edwin J. Castellanos. 2007. Institutions, Biophysical Factors and History: An Integrative Analysis of Private and Common Property Forests in Guatemala and Honduras. Human Ecology [online prepublication]. URL: http://www.springerlink.com/content/m227255371131123/fulltext.pdf. 
Sustainable Social-Ecological Systems: An Impossibility?

Elinor Ostrom

UNEP-WCMC (United Nations Environmental Programme World Conservation Monitoring Centre). 2004. Defining Protected Area Management Categories. Protected Areas and World Heritage Programme. URL: http://www.unep-cmc.org/index.html?http://www.unepwcmc.org/protected areas/categories/ main

Van Berkel, Rik, and Paul van der Aa. 2005. The Marketization of Activation Services: A Modern Panacea? Some Lessons from the Dutch Experience. Journal of European Social Policy 15(4):329343.

Von Weizsaecker, Ernst Ulrich, Oran Young, and Mattias Finger. 2005. Limits to Privatisation - How to Avoid Too Much of a Good Thing. London: Earthscan.

Wagner, Johan C. 1989. Privatisation panacea. Working paper. Cape Town, South Africa: The Water Institute of Southern Africa.

Walker, Brian, and Marco A. Janssen. 2002. Rangelands, Pastoralists and Governments - Inter-Linked Systems of People and Nature. Philosophical Transactions of the Royal Society London: Biological Sciences 357:719-725.

Walters, C. J. 1986. Adaptive Management of Renewable Resources. New York: Macmillan.

Walters, C. J. 1997. Challenges in Adaptive Management of Riparian and Coastal Ecosystems. Conservation Ecology 1(2):1 [online]. URL: http://www.ecologyandsociety.org/vol1/iss2/art1/.

Williams, Michael. 2003. Deforesting the Earth: From Prehistory to Global Crisis. Chicago: University of Chicago Press.

Wilson, James A. 2002. Scientific Uncertainty, Complex Systems, and the Design of Common-Pool Institutions. In The Drama of the Commons, ed. Committee on the Human Dimensions of Global Change, National Research Council, 327-359. Washington, DC: National Academies Press. URL: http://www.nap.edu/books/0309082501/html/.

Wilson, James A., James M. Acheson, Mark Metcalfe, and Peter Kleban. 1994. Chaos, Complexity, and Community Management of Fisheries. Marine Policy 18:291-305.

Wilson, James A., Liying Yan, and Carl Wilson. 2007. Modeling the preconditions for governance in the Maine lobster fishery. Working paper. Orono: University of Maine.

Wilson, James A., Bobbi Low, Robert Costanza, and Elinor Ostrom. 1999. Scale Misperceptions and the Spatial Dynamics of a Social-Ecological System. Ecological Economics 31(2):243-257.

Yaron, Dan, and Ariel Dinar. 1982. Optimal Allocation of Irrigation Water. American Journal of Agricultural Economies 64:681-689.

Young, Oran. 2002. The Institutional Dimensions of Environmental Change. Cambridge, MA: MIT Press.

Young, Oran. 2006. Building regimes for socio-ecological systems: the diagnostic method. Working paper. Santa Barbara: University of California.

Young, Oran, Frans Berkhout, Gilberto C. Gallopin, Marco A. Janssen, Elinor Ostrom, and Sander van der Leeuw. 2006. How Will Globalization Affect the Resilience, Vulnerability, and Adaptability of Socio-Ecological Systems at Various Scales? An Agenda for Scientific Research. Global Environmental Change 16(3):304-316. 